\title{
Non-Avian Reptiles of the state of Rio de Janeiro, Brazil: status of knowledge and commented list
}

\author{
Jane C.F. Oliveira, ${ }^{1,4}$; Rodrigo Castellari Gonzalez ${ }^{2,5}$; Paulo Passos ${ }^{2,6}$; Davor Vrcibradic ${ }^{3,7}$ \& Carlos Frederico Duarte Rocha ${ }^{1,8}$ \\ 1 Universidade do Estado do Rio de Janeiro (UERJ), Instituto de Biologia Roberto Alcântara Gomes (IBRAG), Departamento de Ecologia (DECOL). \\ Rio de Janeiro, RJ, Brasil. \\ ${ }^{2}$ Universidade Federal do Rio de Janeiro (UFRJ), Museu Nacional (MN), Departamento de Vertebrados. Rio de Janeiro, RJ, Brasil. \\ ${ }^{3}$ Universidade Federal do Estado do Rio de Janeiro (UNIRI0), Centro de Ciências Biológicas e da Saúde (CCBS), Instituto de Biociências. \\ Rio de Janeiro, RJ, Brasil. \\ ${ }^{4}$ ORCID: http://orcid.org/0000-0001-5084-1420. E-mail: janeherpeto@gmail.com (corresponding author) \\ ${ }^{5}$ ORCID: http://orcid.org/0000-0001-7164-8363. E-mail: rodcastgon@gmail.com \\ ${ }^{6}$ ORCID: http://orcid.org/0000-0002-1775-0970. E-mail: atractus@gmail.com \\ ${ }^{7}$ ORCID: http://orcid.org/0000-0002-6355-3441.E-mail: davor.vrcibradic@gmail.com \\ ${ }^{8}$ ORCID: http://orcid.org/0000-0003-3000-1242. E-mail: cfdrocha@gmail.com
}

\begin{abstract}
We assessed the current knowledge on non-avian reptile species composition in the state of Rio de Janeiro (RJ), southeastern Brazil. We used published data in indexed journals and verified voucher specimens housed in the herpetological collections of the Museu Nacional (UFRJ), and the Laboratory of Reptiles (ZUFRJ). We also confirmed vouchers from Instituto Vital Brazil (IVB) and from the Museum of Comparative Zoology (MCZ). We compiled a list containing 149 species of reptiles, distributed among Testudines $(N=15)$, Crocodylia $(N=1)$ and Squamata $(N=133$; six amphisbaenians, 38 lizards and 89 snakes). Our results add 20 species to the previous list known for the state. Four species recorded are endemic to the state of Rio de Janeiro (Anolis neglectus, Glaucomastix littoralis, Leposternon scutigerum, and Liolaemus lutzae). We identified that 21 reptile species recorded in RJ state (nearly $15 \%$ of the total) are included in some threat category either in the IUCN, Brazilian (ICMBio) or state lists of endangered species. We also report that seven of the reptiles recorded are non-indigenous to the state: Cnemidophorus aff. lemniscatus (= Cnemidophorus cryptus), Anolis sagrei, Trachemys scripta, Trachemys dorbigni, Hemidactylus mabouia, Crotalus durissus terrificus, and Rhinoclemmys punctularia. The checklist presented here provides a comprehensive database for further research on the herpetofauna of the Brazilian Atlantic Forest.
\end{abstract}

Key-Words. Atlantic Forest; Conservation; Crocodylia; Squamata; Testudines.

\section{INTRODUCTION}

One of the most important steps for the conservation of a given region is the compilation of reliable data on its species composition. Brazil is megadiverse (Rodrigues, 2005), and the country's non-avian reptile (hereafter - reptile) fauna represents a considerable component of its biodiversity. The Brazilian reptile fauna comprises ca. 842 valid species, arranged in the orders Testudines (37 species), Crocodylia (six species) and Squamata (799 species, which includes 75 amphisbaenians, 282 lizards, and 442 snakes) (Costa \& Bérnils, 2018). The Atlantic Forest (AF) is considered a hotspot for biodiversity conservation (Myers et al., 2000; Colombo \& Joly, 2010) housing a third of the country's reptile richness, i.e., approximately 300 species (Tozetti et al., 2018). Despite its considerable biological diversity, the AF has suffered intense deforestation over the past five centuries, and its current scenario is extremely concerning (Pinto et al., 2006; Rocha et al., 2007; Bergallo et al., 2009; Colombo \& Joly, 2010).

The state of Rio de Janeiro (RJ), in southeastern Brazil, is located entirely within the Atlantic Forest domain. Nowadays, the forest cover of Rio de Janeiro is reduced to only 820,164 hectares (SOS Mata Atlântica/INPE 2017/2018), although the original forest cover of the state is estimated to have been approximately 4,294,000 hectares in 1500 (SOS Mata Atlântica/INPE 1992/1993; Rocha et al., 2003). This remaining forest is composed almost entirely of small, isolated fragments, with limited connectivity among them (Ranta et al., 1998; Rocha et al., 2006; Ribeiro et al., 2009; Colombo \& Joly, 2010). The state's once-continuous forest has been reduced to 15,159 fragments smaller than 100 hectares, 42 fragments of 100-1,000 ha, three remnants of 1,000-5,000 ha, and only three larger than 5,000 ha (Rocha et al., 
2006). Additionally, many areas of Rio de Janeiro state are poorly sampled, especially for reptiles (e.g., Vrcibradic et al., 2011), indicating persistent knowledge bias on the composition of the reptile communities in many areas (Rocha et al., 2009a).

The first comprehensive inventory on the reptile species of RJ state was published about 15 years ago (Rocha et al., 2004), in which 127 species of reptiles were known to occur in the state (one crocodilian, seven amphisbaenians, nine chelonians, 28 lizards and 82 snakes). A number of subsequent studies have increased the knowledge on reptile composition of RJ by inventorying areas in the state (e.g., Citeli et al., 2016; Rocha et al., 2018; Martins et al., 2019) extending the geographic distribution of some species (e.g., Silveira, 2008; GoyannesAraújo et al., 2009; Hamdan et al., 2015), describing new taxa (e.g., Fernandes et al., 2010; Prates et al., 2020), and providing new records of non-indigenous species (e.g., Siciliano et al., 2014; Oliveira et al., 2018). The recent advances, along with a number of additional taxonomic adjustments through the years (e.g., Sturaro et al., 2018; Hoogmoed et al., 2019), made the species list of RJ become outdated. Therefore, there was a need to update the state's species list in order to facilitate conservation and management strategies and, to reinforce the need for studies on the current species distribution.

Here, we provide an updated list of the reptiles occurring in the state of Rio de Janeiro, which we hope will serve as an important database for future research on the state's reptile fauna.

\section{MATERIAL AND METHODS}

We compiled the existing records of the reptile species composition of Rio de Janeiro state (Fig. 1) from the following data sources: (1) voucher specimens housed in the herpetological collection of the Museu Nacional (MNRJ) and Zoological Collection (ZUFRJ), both part of the Universidade Federal do Rio de Janeiro (UFRJ). We also considered vouchers from the Instituto Vital Brazil (IVB), in Niterói, state of Rio de Janeiro, and from the Museum of Comparative Zoology, Cambridge, USA; (2) scientific papers published in indexed journals (e.g., SCOPUS, Scielo, Web of Science). In the search for literature data, we accessed bibliographic databases searching for academic articles by using the combination of keywords: "squamata* and Rio de Janeiro", "herpeto* and Rio de Janeiro", "new and reptile and Rio de Janeiro", "snake* and Rio de Janeiro", "lizard* and Rio de Janeiro". We restricted our search to papers published between 2000 and 2019. We excluded from the list all species which the occurrence in Rio de Janeiro could not be confirmed either by a voucher or a published report. In the herpetological collection, we identified the species based on the appropriate taxonomic reviews available for each reptil-

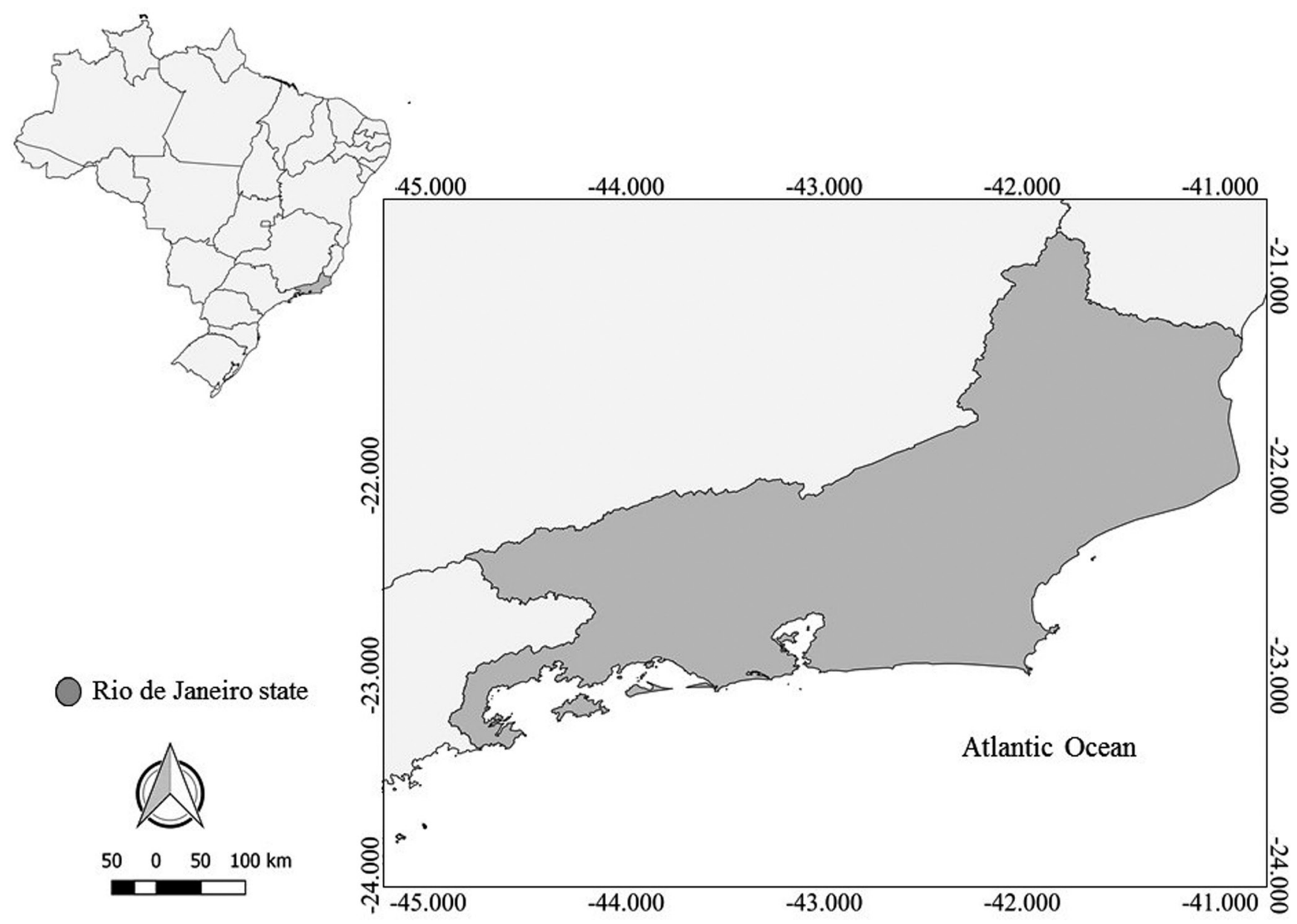

Figure 1. State of Rio de Janeiro (enlarged figure in right frame) located in southeastern Brazil (in darker gray in the upper left figure). 
ian group. We considered that the consulted collections adequately represent the species occurring in the state of Rio de Janeiro.

We followed the nomenclature of Costa \& Bérnils (2018) except for the genus Anolis (lato sensu), for which we decided to use the most conservative proposal (Poe et al., 2017 instead of Nicholson et al., 2018). We adopted Borges-Martins' (1998) classification of the Ophiodes species, given that this is the most complete review of the group, although data have not yet been published. Additionally, we also considered nomenclatural changes posterior to the publication of Costa \& Bérnils (2018), such as the synonymizations of Cercosaura ocellata ocellata with C. olivacea Gray, 1845 (Sturaro et al., 2018), Sibynomorphus with Dipsas (Arteaga et al., 2018), and Uromacerina ricardinii with Cercophis auratus (Hoogmoed et al., 2019) and the transfer of Mastigodryas bifossatus to the genus Palusophis (Montingelli et al., 2019).

We classified each reptile species as endemic to the state of Rio de Janeiro based on scientific papers published (see literature review method above). We also consulted lists containing the conservation status of each species in the state of Rio de Janeiro (Rocha et al., 2000), the red book of Brazilian fauna (ICMBio, 2018), and the IUCN Red List (2019). The classification is standardized by the IUCN categories, i.e., Data Deficient (DD), Near Threatened (NT), Endangered (EN), Vulnerable (VU),
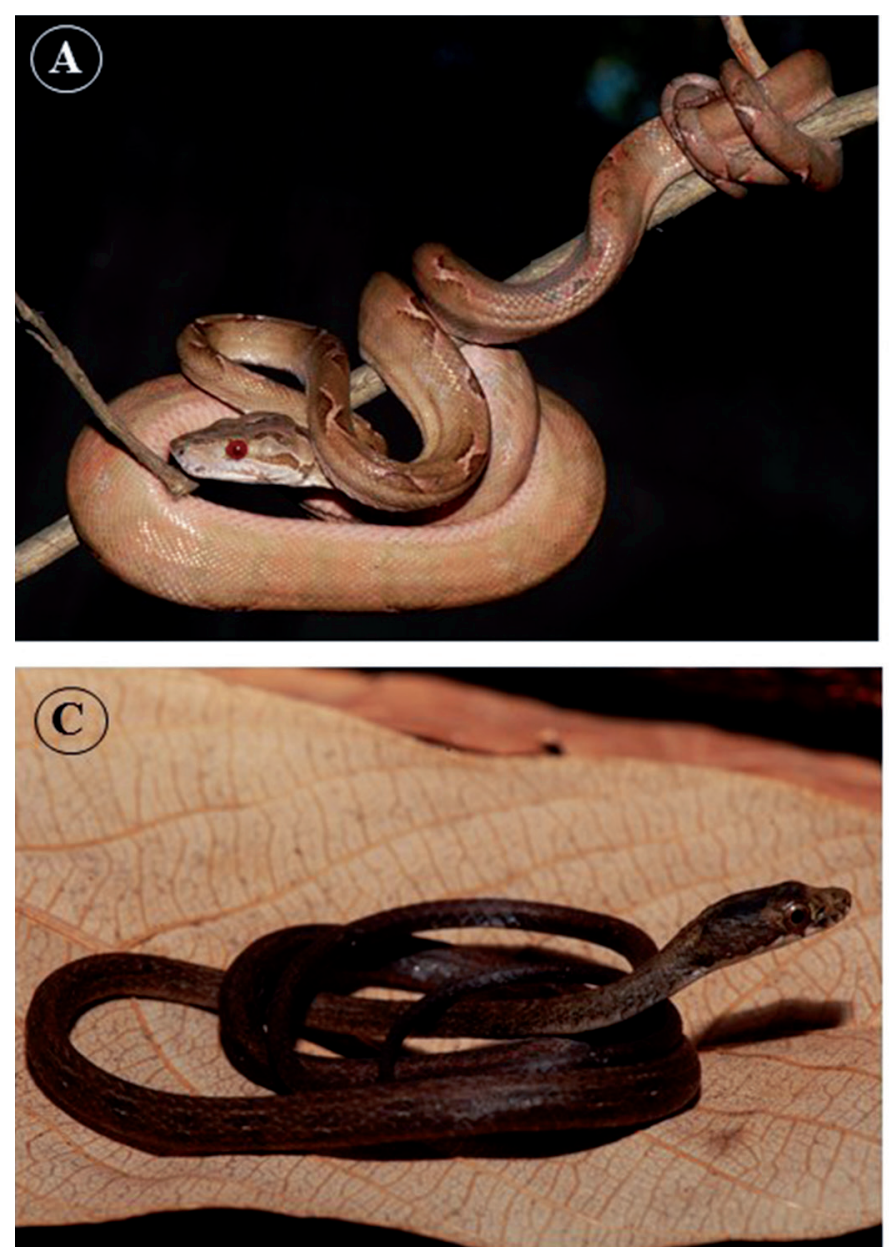

Critically Endangered (CR), or Probably Extinct (PEx - following Rocha et al., 2000).

\section{RESULTS AND DISCUSSION}

We compiled a list of 149 reptile species currently known to occur in the state of Rio de Janeiro (Table 1, Fig. 2), belonging to Crocodylia $(N=1)$, Testudines $(\mathrm{N}=15)$, and Squamata ( $\mathrm{N}=133$, including six amphisbaenians, 38 lizards and 89 snakes). Overall, 18 of these species were previously addressed in the literature as subspecies (Table 1), but as none of these species are represented by more than a single subspecies in Rio de Janeiro state, so each taxon was counted as a single species for the estimates of species richness.

The total reptile species richness confirmed here for Rio de Janeiro state $\left(\mathrm{N}_{\text {total }}=149\right)$ represents approximately $19 \%$ of the reptiles reported to occur in Brazil $\left(\mathrm{N}_{\text {total }}=795\right.$; Costa \& Bérnils, 2018), and around half of the ca. 300 reptile species believed to occur in the Atlantic Forest Biome (Tozetti et al., 2018). When analyzed by order, the proportion of the Brazilian reptiles found in Rio de Janeiro state varied considerably. The six amphisbaenians from this state, for example, represent $8 \%$ of the 72 species known to occur in Brazil, whereas at the opposite extreme, the 15 turtles represent $42 \%$ of the Brazilian
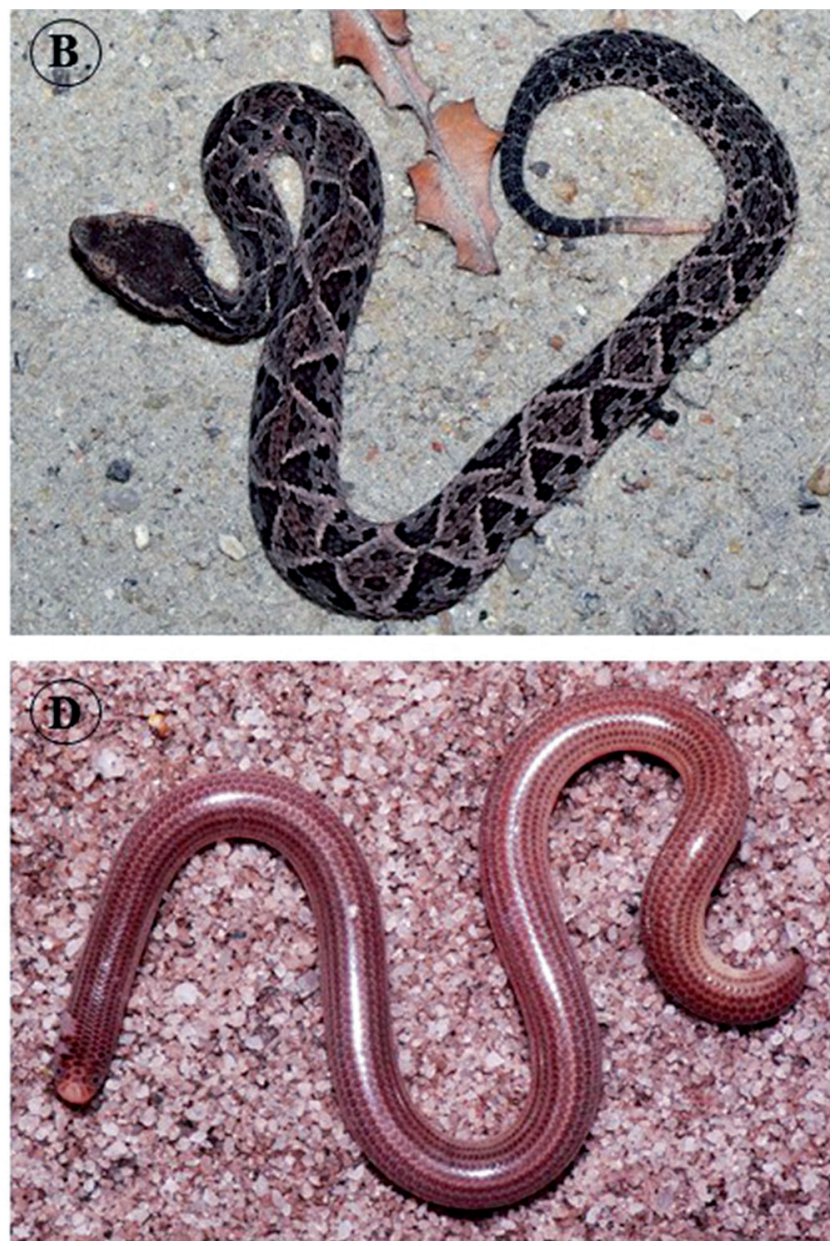

Figure 2A-D. Some reptile species recorded in Rio de Janeiro state: (A) Corallus hortulanus (Photo: Pedro Pinna), (B) Bothrops jararacussu (Photo: Pedro Pinna), (C) Cercophis auratus (Photo: Pedro Pinna), (D) Amerotyphlops brongersmianus (Photo: Pedro Pinna). 
chelonian fauna (36 species). Rio de Janeiro also has 14\% $(\mathrm{N}=38)$ of the 276 Brazilian lizard species, $17 \%(\mathrm{~N}=1)$ of six crocodilians, and $22 \%(\mathrm{~N}=88)$ of its 405 snake species. These results reinforce the importance of the Atlantic Forest biome for the conservation of the reptile biodiversity of Brazil.

Compared to the previous inventory of Rocha et al. (2004), our results led to the removal of 11 species and the addition of 31 species, representing an increase of 20 species (Table 1). Taxa were removed from the list for two reasons: the result of taxonomic arrangement of some groups, such as the restriction of Atractus maculatus to northeastern Brazil (Passos et al., 2010), and the exclusion of taxa with no voucher specimens in a museum collection to corroborate the occurrence of the species in the state (e.g., Lepidodactylus lugubris and Oxyrhopus rhombifer).

The taxa added to the list (Table 1) refer to the description of new taxa, such as Dipsas sazimai (Fernandes et al., 2010) and Anolis neglectus (Prates et al., 2020) and the addition of new records of non-indigenous taxa, such as Cnemidophorus aff. lemniscatus (as C. cryptus; Oliveira et al., 2015), and A. sagrei (Oliveira et al., 2018) whether or not a viable population had been established. Another reason was the extension of the geographic range of some species, such as Anolis fuscoauratus (GoyannesAraújo et al., 2009).
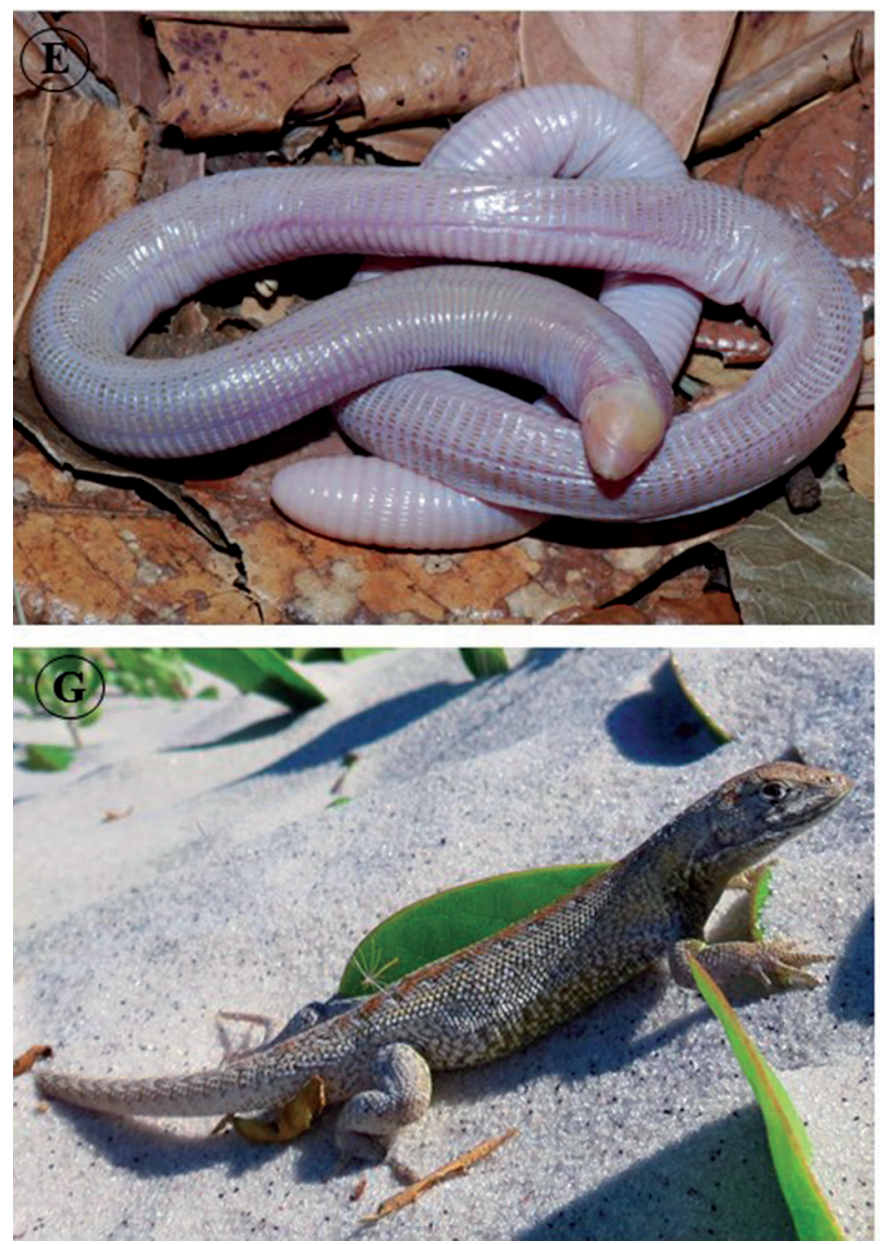

We recorded four endemic reptile species to Rio de Janeiro state: Anolis neglectus, Glaucomastix littoralis, Leposternon scutigerum, and Liolaemus lutzae. Three of these are also considered to be threatened: Liolaemus lutzae, Glaucomastix litorallis, and Leposternon scutigerum (Table 1). Glaucomastix littoralis is currently known to occur at only four localities: Barra de Maricá, Restinga da Marambaia, Jurubatiba National Park, and Grussaí. Liolaemus lutzae occurs in coastal areas from Restinga da Marambaia to Cabo Frio (Rocha et al., 2009b), while L. scutigerum is known to occur between the coastal municipalities of Macaé and Niterói. These three species occur in Restinga habitats (sandy coastal plain formations) and are threatened primarily by the ongoing fragmentation and loss of habitats to coastal development (Rocha et al., 2003). In the past, these restingas covered almost the whole of the coast of Rio de Janeiro state, except for rocky sectors (Rocha et al., 2003), but are now subject to an accelerated process of degradation due to the expansion of real estate in the area. Anolis neglectus was recently described from Parque Nacional da Serra dos Órgãos, in the municipality of Teresópolis and the population is restricted to a small secondary montane Atlantic Forest vegetation within this Park.

We confirmed the presence of seven non-indigenous reptile taxa in Rio de Janeiro state: Trachemys scripta, T. dorbigni, Rhinoclemmys punctularia, A. sagrei,

Figure 2E-H. Some reptile species recorded in Rio de Janeiro state: (E) Leposternon scutigerum (Photo: Pedro Pinna), (F) Hydromedusa maximiliani (Photo: Pedro Pinna), (G) Liolaemus lutzae (Photo: Patrícia Almeida-Santos); (H) Anolis neglectus (Photo: Leandro Drummond). 
Cnemidophorus aff. lemniscatus, Hemidactylus mabouia, and Crotalus durissus terrificus. The red-eared turtle, T. scripta, whose native range is the eastern United States (e.g., Ernst \& Lovich, 2009; Powell et al., 2016), was recorded in Tijuca National Park, but it was probably released intentionally into the wild, given that the species was encountered in a highly impacted area within the urban zone of the city of Rio de Janeiro (Dorigo, 2017). The BlackBellied Slider, T. dorbigni, was originally known to occur only in the Brazilian state of Rio Grande do Sul (Fritz \& Havas, 2006), thousands of kilometers to the south of Rio de Janeiro, and is also likely to have been released into the wild, rather than reaching the state unaided (Salles \& Silva-Soares, 2010). Although we have no evidence that either T. scripta or T. dorbigni has established a viable wild population in the state of Rio de Janeiro, it does seem possible that established populations can be found in urban parks, particularly in the state capital. Rhinoclemmys punctularia, a semi-aquatic turtle, naturally distributed in the Amazon region, north of Brazil (Ávila-Pires et al., 2010; Wariss et al., 2012), was recorded in the Pássaros Natural Municipal Park in the municipality of Rio das Ostras, and also in the municipality of Cabo Frio, in eastern Rio de Janeiro state. While R. punctularia may also have been introduced into Rio de Janeiro via the illegal pet trade, the possibility that it represents a relictual population cannot be ruled out altogether (Siciliano et al., 2014), given
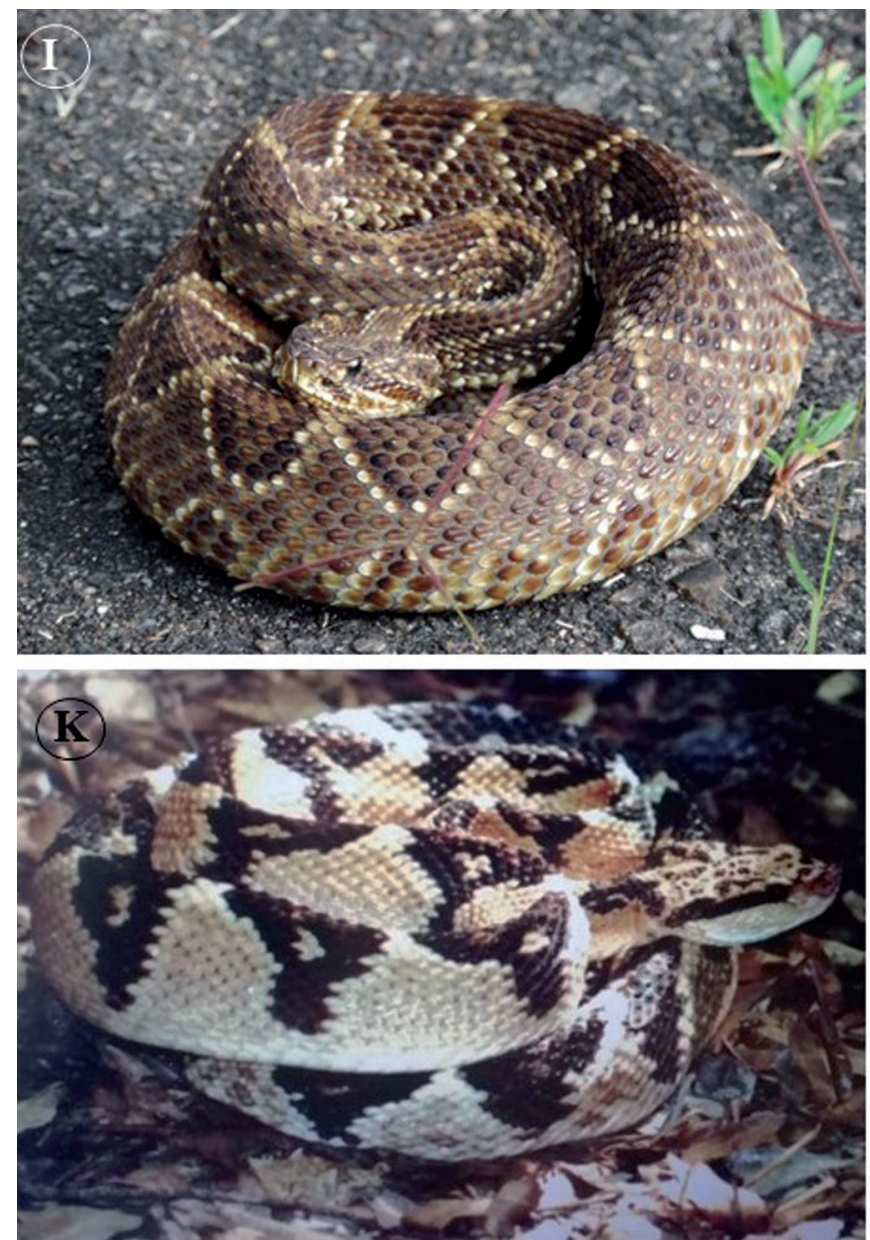

that a second Rhinoclemmys species has been recently discovered (currently under description by Caramaschi et al., in. prep.) in the neighboring state of Espírito Santo.

Three non-indigenous lizard species are known to have established populations in the state: Anolis sagrei (Oliveira et al., 2018), Cnemidophorus aff. lemniscatus (formerly treated as Cnemidophorus cryptus; Oliveira et al., 2015), and Hemidactylus mabouia (e.g., Rocha \& Bergallo, 2011). Anolis sagrei and C. aff. lemniscatus were recently discovered within the perimeter of Galeão International Airport on Ilha do Governador island, in the eastern extreme of the state capital, Rio de Janeiro (Oliveira et al., 2018). Anolis sagrei is native to Cuba, the Bahamas, and the Cayman Islands, but has been detected as an invasive species in several countries in the Americas and Asia (e.g., Kolbe et al., 2004). Anolis sagrei was suggested to have been transported to that site in RJ unintentionally in the cargo of arriving aircraft (Oliveira et al., 2018). Lizards of the Cnemidophorus lemniscatus complex are known to occur in the Amazon region and the records in southeastern Brazil are probably introduced populations (Oliveira et al., 2015). We are currently conducting a molecular analysis of $C$. aff. lemniscatus in an attempt to identify the origin of these lizards (Oliveira et al., in prep.). By contrast, the presence of the African gecko H. mabouia in Rio de Janeiro is much older, dating back to colonial times, when it crossed the Atlantic Ocean at
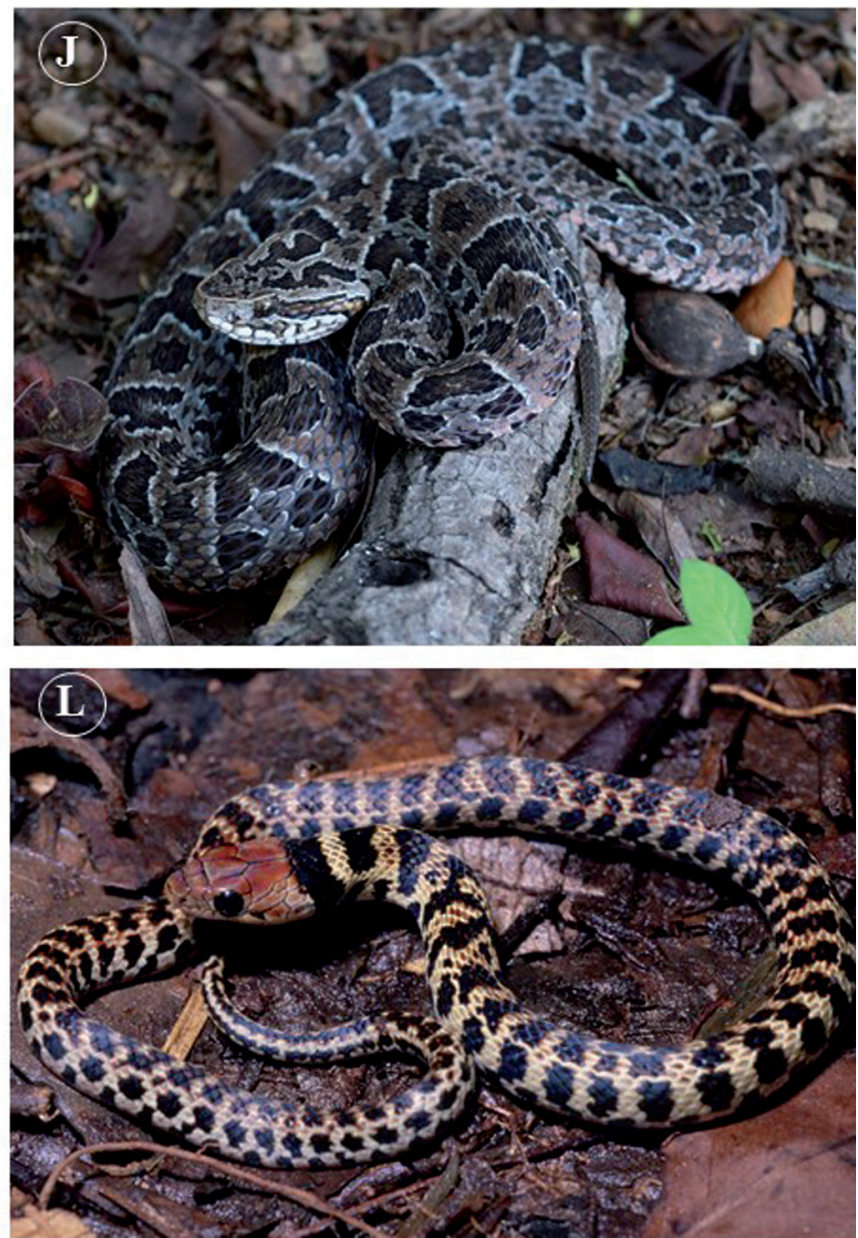

Figure 2I-L. Some reptile species recorded in Rio de Janeiro state: (I) Crotalus durissus (Photo: Edson Ferreira Santiago); (J) Bothrops neuwiedi (Photo: Marcelo Ribeiro Duarte); (K) Lachesis muta (Photo: Marcos Felipe da Rocha Pinto); (L) Erythrolamprus poecilogyrus poecilogyrus (Photo: Otávio Marques). 
Table 1. Reptile species recorded in the Rio de Janeiro state, southeastern Brazil along with their conservation status. Threatened species lists: ICMBio $=$ Livro Vermelho da Fauna Brasileira Ameaçada de Extinção ICMBio/MMA (2018); IUCN = The International Union for Conservation of Nature's Red List of Threatened Species (IUCN, 2019); RJ = Rio de Janeiro State List of Endangered Species (Rocha et al., 2000). Status: ${ }^{*}=$ Non-Indigenous species in Rio de Janeiro; $(R=$ Critically endangered; $\mathrm{DD}=$ Deficient data; $\mathrm{EN}=$ Endangered; ${ }^{\mathrm{END}}=$ endemic reptile species of Rio de Janeiro state; $\mathrm{LC}=$ Least Concern; Pex $=$ Probably extinct; $\mathrm{VU}=\mathrm{Vulnerable}$.

\begin{tabular}{|c|c|c|c|}
\hline \multirow{2}{*}{ Táxon } & \multicolumn{3}{|c|}{ Conservation status } \\
\hline & IUCN & ICMBio & RJ \\
\hline \multicolumn{4}{|c|}{ TESTUDINES Batsch, 1788} \\
\hline \multicolumn{4}{|l|}{ Chelidae Gray, 1825} \\
\hline Acanthochelys radiolata (Mikan, 1820) & - & $\mathrm{LC}$ & DD \\
\hline Hydromedusa maximiliani (Mikan, 1820) & VU & DD & - \\
\hline Hydromedusa tectifera Cope, 1869 & - & $\mathrm{LC}$ & - \\
\hline Mesoclemmys hogei (Mertens, 1967) & CR & CR & VU \\
\hline Phrynops geoffroanus (Schweigger, 1812) & - & - & 一 \\
\hline \multicolumn{4}{|l|}{ Cheloniidae Oppel, 1811} \\
\hline Caretta caretta (Linnaeus, 1758) & VU & EN & VU \\
\hline Chelonia mydas (Linnaeus, 1758) & EN & VU & VU \\
\hline Eretmochelys imbricata (Linnaeus, 1766) & $C R$ & CR & VU \\
\hline Lepdochelys olivacea (Eschscholtz, 1829) & VU & EN & VU \\
\hline \multicolumn{4}{|l|}{ Dermoheclyidae Fitzinger, 1843} \\
\hline Dermochelys coriacea (Linnaeus, 1766) & VU & CR & VU \\
\hline \multicolumn{4}{|l|}{ Emydidae Rafinesque, 1815} \\
\hline Trachemys scripta (Thunberg In Schoepff, 1792)* & - & - & - \\
\hline \multicolumn{4}{|l|}{ Trachemys dorbigni (Duméril \& Bibron, 1835) * } \\
\hline \multicolumn{4}{|l|}{ Geoemydidae Theobald, 1868} \\
\hline Rhinoclemmys punctularia (Daudin, 1801)* & - & $\mathrm{LC}$ & 一 \\
\hline \multicolumn{4}{|l|}{ Testudinidae Batsch, 1788} \\
\hline Chelonoidis carbonarius (Spix, 1824) & - & - & $\mathrm{LC}$ \\
\hline Chelonoidis denticulatus (Linnaeus, 1766) & - & $\mathrm{LC}$ & - \\
\hline
\end{tabular}

\section{Alligatoridae Cuvier, 1807}

Caiman latirostris (Daudin, 1802)

CROCODYLIA Gmelin, 1789

\section{SQUAMATA Oppel, 1811 (Amphisbaenia)}

\section{Amphisbaenidae Gray, 1825}

$\mathrm{LC}$

LC

EN

Amphisbaena alba Linnaeus, 1758

Amphisbaena darwinii Duméril \& Bibron, 1839

Leposternon infraorbitale (Berthold, 1859)

Leposternon microcephalum Wagler in Spix, 1824

Leposternon scutigerum (Hemprich, 1820) END

Leposternon wuchereri (Peters, 1879)

\section{SQUAMATA Oppel, 1811 (lizards)}

\section{Anguidae Gray, 1825}

Diploglossus fasciatus (Gray, 1831)

- $\mathrm{LC}$

Ophiodes striatus (Spix, 1824)

Dactyloidae Fitzinger, 1843

Anolis fuscoauratus (D'Orbigny in Duméril \& Bibron, 1837)

Anolis neglectus Prates, Melo-Sampaio, Queiroz, Carnaval, Rodrigues and Drummond, 2020 END

Anolis punctatus (Daudin, 1802)

Anolis sagrei Duméril \& Bibron, $1837^{*}$

\section{Gekkonidae Gray, 1825}

Hemidactylus mabouia (Moreau de Jonnès, 1818)*

\section{Gymnophthalmidae Fitzinger, 1826}

Cercosaura olivacea Gray, 1845

Cercosaura quadrilineata Boettger, 1876

Colobodactylus dalcyanus Vanzolini \& Ramos, 1977

Ecpleopus gaudichaudii Duméril \& Bibron, 1839

Heterodactylus imbricatus Spix, 1825

Leposoma scincoides Spix, 1825

Micrablepharus maximiliani (Reinhardt \& Luetken, 1862)

Placosoma cordylinum Tschudi, 1847

Placosoma glabellum (Peters, 1870)

$\mathrm{LC}$

$-$

LC

DD

-

$-$

-

-

-

$\begin{array}{ll}- & - \\ - & - \\ \mathrm{EN} & - \\ - & - \\ \mathrm{LC} & - \\ \mathrm{LC} & - \\ \mathrm{LC} & - \\ \mathrm{LC} & - \\ \mathrm{LC} & -\end{array}$




\begin{tabular}{|c|c|c|c|}
\hline \multirow{2}{*}{ Táxon } & \multicolumn{3}{|c|}{ Conservation status } \\
\hline & IUCN & ICMBio & RJ \\
\hline \multicolumn{4}{|l|}{ Leiosauridae Frost, Etheridge, Janies \& Titus, 2001} \\
\hline Anisolepis grilli Boulenger, 1891 & - & $\mathrm{LC}$ & - \\
\hline Enyalius bilineatus Duméril \& Bibron, 1837 & - & $\mathrm{LC}$ & - \\
\hline Enyalius brasiliensis (Lesson, 1828) & - & $\mathrm{LC}$ & - \\
\hline Enyalius iheringii Boulenger, 1885 & - & $\mathrm{LC}$ & - \\
\hline Enyalius perditus Jackson, 1978 & - & $\mathrm{LC}$ & $\mathrm{DD}$ \\
\hline Urostrophus vautieri Duméril \& Bibron, 1837 & - & $\mathrm{LC}$ & - \\
\hline \multicolumn{4}{|l|}{ Liolaemidae Frost \& Etheridge, 1989} \\
\hline Liolaemus lutzae Mertens, 1938 END & VU & CR & VU \\
\hline \multicolumn{4}{|l|}{ Mabuyidae Mittleman, 1952} \\
\hline Aspronema dorsivittatum (Cope, 1862) & - & $\mathrm{LC}$ & - \\
\hline Brasiliscincus agilis (Raddi, 1823) & - & $\mathrm{LC}$ & - \\
\hline \multicolumn{4}{|l|}{ Notomabuya frenata (Cope, 1862) } \\
\hline Psychosaura macrorhyncha (Hoge, 1947) & 一 & $\mathrm{LC}$ & 一 \\
\hline \multicolumn{4}{|l|}{ Polychrotidae Fitzinger, 1843} \\
\hline Polychrus marmoratus (Linnaeus, 1758) & - & $\mathrm{LC}$ & 一 \\
\hline \multicolumn{4}{|l|}{ Phyllodactylidae Gamble, Bauer, Greenbaum \& Jackman, 2008} \\
\hline Gymnodactylus darwinii (Gray, 1845) & - & $\mathrm{LC}$ & 一 \\
\hline \multicolumn{4}{|l|}{ Teiidae Gray, 1827} \\
\hline Ameiva ameiva (Linnaeus, 1758) & - & $\mathrm{LC}$ & - \\
\hline \multicolumn{4}{|l|}{ Cnemidophorus aff. lemniscatus (Linnaeus, 1758)* } \\
\hline Glaucomastix littoralis (Rocha, Araújo, Vrcibradic \& Costa, 2000) END & - & EN & - \\
\hline Salvator merianae Duméril \& Bibron, 1839 & - & $\mathrm{LC}$ & - \\
\hline \multicolumn{4}{|l|}{ Tropiduridae Bell in Darwin, 1843} \\
\hline Tropidurus hispidus (Spix, 1825) & - & $\mathrm{LC}$ & - \\
\hline Tropidurus torquatus (Wied, 1820) & - & $\mathrm{LC}$ & - \\
\hline Strobilurus torquatus Wiegmann, 1834 & - & $\mathrm{LC}$ & - \\
\hline
\end{tabular}

SQUAMATA Oppel, 1811 (snakes)

\section{Anomalepididae Taylor, 1939}

Liotyphlops wilderi (Garman, 1883)

\section{Boidae Gray, 1825}

Boa constrictor constrictor Linnaeus, 1758

Corallus hortulanus (Linnaeus, 1758)

Epicrates cenchria (Linnaeus, 1758)

\section{Colubridae Oppel, 1811}

Chironius bicarinatus (Wied, 1820)

Chironius exoletus (Linnaeus, 1758)

Chironius foveatus Bailey, 1955

Chironius fuscus (Linnaeus, 1758)

Chironius laevicollis (Wied, 1824)

Chironius quadricarinatus (Boie, 1827)

Drymarchon corais corais (Boie, 1827)

Drymoluber dichrous (Peters, 1863)

Leptophis ahaetulla liocercus (Wied, 1824)

Oxybelis aeneus aeneus (Wagler In Spix, 1824)

Spilotes pullatus pullatus (Linnaeus 1758)

Spilotes sulphureus poecilostoma (Wied, 1825)

Tantilla aff. melanocephala (Linnaeus 1758)

Dipsadidae Bonaparte, 1838

Atractus francoi Passos, Fernandes, Bérnils \& Moura-Leite, 2010

Atractus zebrinus (Jan, 1862)

Caaeteboia amarali (Wettstein, 1930)

Cercophis auratus (Schlegel 1837)

Clelia plumbea (Wied, 1820)

Coronelaps lepidus (Reinhardt, 1861)

Dipsas albifrons (Sauvage, 1884)

Dipsas alternans (Fischer, 1885)

Dipsas indica petersi (Fischer, 1885)

Dipsas neuwiedi (Ihering, 1911)

Dipsas sazimai Fernandes, Marques \& Argôlo, 2010

Dipsas variegata (Duméril, Bibron \& Duméril, 1854)

Echinanthera amoena (Jan, 1863)

Echinanthera cephalostriata Di-Bernardo, 1996

\begin{tabular}{|c|c|c|}
\hline- & $\mathrm{LC}$ & - \\
\hline- & $\mathrm{LC}$ & - \\
\hline- & $\mathrm{LC}$ & - \\
\hline- & $\mathrm{LC}$ & - \\
\hline- & $\mathrm{LC}$ & - \\
\hline- & $\mathrm{LC}$ & - \\
\hline- & $\mathrm{LC}$ & - \\
\hline- & $\mathrm{LC}$ & - \\
\hline- & $\mathrm{LC}$ & - \\
\hline- & $\mathrm{LC}$ & - \\
\hline- & $\mathrm{LC}$ & - \\
\hline- & $\mathrm{LC}$ & - \\
\hline- & $\mathrm{LC}$ & - \\
\hline- & $\mathrm{LC}$ & - \\
\hline- & $\mathrm{LC}$ & - \\
\hline- & $\mathrm{LC}$ & - \\
\hline- & - & - \\
\hline- & $\mathrm{DD}$ & - \\
\hline- & $\mathrm{LC}$ & - \\
\hline- & $\mathrm{LC}$ & - \\
\hline- & $\mathrm{LC}$ & - \\
\hline- & $\mathrm{LC}$ & - \\
\hline- & $\mathrm{LC}$ & - \\
\hline- & $\mathrm{LC}$ & - \\
\hline- & $\mathrm{LC}$ & - \\
\hline- & $\mathrm{LC}$ & - \\
\hline- & $\mathrm{LC}$ & - \\
\hline- & $\mathrm{LC}$ & - \\
\hline- & $\mathrm{LC}$ & - \\
\hline- & $\mathrm{LC}$ & - \\
\hline- & $\mathrm{LC}$ & - \\
\hline
\end{tabular}


Conservation status

\section{Táxon}

Echinanthera cyanopleura (Cope, 1885)

Echinanthera melanostigma (Wagler In Spix, 1824)

Echinanthera undulata (Wied, 1824)

Elapomorphus quinquelineatus (Raddi, 1820)

Erythrolamprus aesculapii venustissimus (Wied, 1821)

Erythrolamprus almadensis (Wagler, 1824)

Erythrolamprus atraventer (Dixon \& Thomas, 1985)

Erythrolamprus jaegeri jaegeri (Günther, 1858)

Erythrolamprus miliaris merremi (Wied, 1821)

Erythrolamprus poecilogyrus poecilogyrus (Wied, 1825)

Erythrolamprus reginae (Linnaeus, 1758)

Erythrolamprus typhlus brachyurus (Cope, 1887)

Helicops carinicaudus (Wied, 1824)

Imantodes cenchoa (Linnaeus, 1758)

Leptodeira annulata annulata (Linnaeus, 1758)

Mussurana montana (Franco, Marques \& Puorto, 1997)

Oxyrhopus guibei Hoge \& Romano, 1977

Oxyrhopus clathratus Duméril, Bibron \& Duméril, 1854

Oxyrhopus petolarius digitalis (Reuss, 1834)

Oxyrhopus trigeminus Duméril, Bibron \& Duméril, 1854

Palusophis bifossatus (Raddi, 1820)

Paraphimophis rusticus (Cope, 1878)

Philodryas olfersii (Liechtenstein, 1823)

Philodryas patagoniensis (Girard, 1858)

Pseudoboa nigra (Duméril, Bibron \& Duméril, 1854)

Pseudoboa serrana Morato, Moura-Leite, Prudente \& Bérnils, 1995

Siphlophis compressus (Daudin, 1803)

Siphlophis longicaudatus (Andersson, 1901)

Siphlophis pulcher (Raddi, 1820)

Taeniophallus affinis (Günther, 1858)

Taeniophallus bilineatus (Fischer, 1885)

Taeniophallus occipitalis (Jan, 1863)

Taeniophallus persimilis (Cope, 1869)

Thamnodynastes cf. nattereri (Mikán, 1828)

Thamnodynastes hypoconia (Cope, 1860)

Thamnodynastes longicaudus Franco, Ferreira, Marques \& Sazima, 2003

Thamnodynastes strigatus (Günther, 1858)

Tomodon dorsatus Duméril, Bibron \& Duméril, 1854

Tropidodryas serra (Schlegel, 1837)

Tropidodryas striaticeps (Cope, 1870)

Xenodon merremii (Wagler In Spix, 1824)

Xenodon neuwiedii Günther, 1863

Xenopholis scalaris (Wucherer, 1861)

\section{Elapidae Boie, 1827}

Micrurus aff. ibiboboca (Merrem, 1820)

Micrurus corallinus (Merrem, 1820)

Micrurus decoratus (Jan, 1858)

Micrurus lemniscatus carvalhoi Roze, 1967

Leptotyphlopidae Stejneger, 1892

Trilepida salgueiroi (Amaral, 1955)

Tropidophiidae Brongersma, 1951

Tropidophis paucisquamis (Müller, 1901)

Typhlopidae Merrem, 1820

Amerotyphlops brongersmianus (Vanzolini, 1976)

\section{Viperidae Oppel, 1811}

Bothrops alternatus Duméril, Bibron \& Duméril, 1854

Bothrops bilineatus bilineatus (Wied, 1821)

Bothrops fonsecai Hoge \& Belluomini, 1959

Bothrops jararaca (Wied, 1824)

Bothrops jararacussu Lacerda, 1884

Bothrops neuwiedi (Wagler, 1824)

Crotalus durissus terrificus (Laurenti, 1768)*

Lachesis muta (Linnaeus, 1766)

ICMBio

RJ

IUCN

- li

\section{LC}

\begin{tabular}{lll}
- & $\mathrm{k}$ & - \\
- & $\mathrm{k}$ & - \\
- & $\mathrm{k}$ & - \\
- & $\mathrm{k}$ & - \\
\hline
\end{tabular}

$-$

$\begin{array}{lll}- & \mathrm{LC} & - \\ - & \mathrm{LC} & -\end{array}$


least twice, and was introduced into a number of different countries of the New World (Rocha \& Bergallo, 2011). These geckos live in urban areas and other disturbed habitats in Brazil, and the ongoing deforestation occurring in many areas should facilitate further invasions into previously unoccupied areas (Oliveira et al., 2016). As a result, the area occupied by $H$. mabouia is known to have been expanding progressively into many areas of natural vegetation in Brazil, over the past 80 years, in particular in open, savanna-like habitats (Rocha \& Bergallo, 2011).

Finally, the South American rattlesnake, Crotalus durissus terrificus, occurs naturally in open areas from the states of Rio Grande do Sul to Mato Grosso do Sul and Minas Gerais, Rondônia, Amazonas, and Pará (Campbell \& Lamar, 2004). The first record of $C$. durissus terrificus in the Rio de Janeiro Atlantic Forest was in Itatiaia National Park (Barth, 1957; Bastos et al., 2005). Since then, the occurrence of this snake in the state has become common and its range has been gradually expanding, usually associated with the suppression of native vegetation (Bastos et al., 2005). At least two snake species (Bothrops neuwiedi and Chironius quadricarinatus) are restricted to putative natural open formations in the municipality of Campos do Goytacazes, in the northeastern extreme of the state of Rio de Janeiro. Both species may represent naturally disjunct populations separated from their core distribution in the Cerrado by the expansion of climatic conditions favorable for forest-dwelling species during the Last Glacial Maximum (e.g., Leite et al., 2016).

The records of Iguana iguana in the state of Rio de Janeiro are from the municipality of Cabo Frio in 1951 (MNRJ 12929-30) and there is no current record of the occurrence of this species in the state. The occurrence of I. iguana in RJ is also based on the existence of historical records of the species from the forests of Rio de Janeiro. In the book "Animalia Brasiliensia Lacertae", Spix (1825) described the occurrence of Iguana lophyroides (a junior synonym of I. iguana - Peters \& Donoso-Barros, 1970) in Rio de Janeiro, reporting that it was commonly found on branches in the forests of Rio de Janeiro, "Habitat non rara supra ramos in sylvis Rio de Janeiro" (Spix, 1825). Therefore, we consider that these records suggest the natural occurrence of Iguana iguana in the state of Rio de Janeiro, which represents the southernmost limit of the original distribution of the species.

Twenty-one species from the present list (nearly $14 \%$ of all records) are considered under some degree of threat, either regionally (Rocha et al., 2000), nationally (ICMBio, 2018) or even at global level (IUCN, 2019). These include 15 species listed in Rio de Janeiro (Rocha et al., 2000), 11 in Brazil (ICMBio, 2018), and nine worldwide (IUCN, 2019). Five of these species are Testudines, of which four are marine turtles, which are broadly distributed across the world's oceans (IUCN, 2019). Despite the wide distribution of species, several factors are related to the decline in marine turtle populations, for example, the harvesting of adults and eggs (Jackson et al., 2001). Brazil has taken considerable steps toward the conservation of marine turtles, in particular, the protection of nesting sites, which is potentially the most important conservation strategy at a local scale.

The broad-snouted caiman, Caiman latirostris, is the only crocodilian species found in Rio de Janeiro state, and is included as "Endangered" in the state's red list (Rocha et al., 2000). The populations of C. latirostris living in the municipality of Rio de Janeiro are of particular concern, given the ongoing urban expansion of Barra da Tijuca that have taken place of their natural habitat, such as lakes that nowadays are reduced to canals with polluted water. The broad-snouted caiman was naturally abundant in the coastal region of RJ, but its populations have been declining considerably mainly due to this strong anthropic pressure (Rocha et al., 2000). There is still a large shortage of studies that assess the relation between the reduction of available natural habitats over the population structures in the state of Rio de Janeiro.

Although the green pit viper, Bothrops bilineatus bilineatus, is listed as "Least Concern" (LC) in national red list (ICMBio, 2018), it is considered to be Probably Extinct (Pex) in the state of Rio de Janeiro (Table 1). Bothrops b. bilineatus has not been reliably documented in the state since 1963, when a specimen was collected in the suburb of Recreio dos Bandeirantes, in the municipality of Rio de Janeiro (Rocha et al., 2000). A second viperid, the bushmaster, Lachesis muta, is also listed as LC in Brazil, but is considered "Endangered" (EN) in Rio de Janeiro (Rocha et al., 2000). Lachesis muta is the largest venomous snake in the New World, and is the world's longest viperid (Campbell \& Lamar, 2004). This forest-dwelling pit viper is known to be particularly sensitive to anthropogenic impacts, and it is thus restricted to areas in which forest remnants are relatively well preserved (Campbell \& Lamar, 2004). The most recent specimen from Rio de Janeiro (voucher specimen IVB1) was collected in 1986 in the municipality of Santa Maria Madalena, in the north of the state. A photographic record of the species was obtained in 2004 in the União Biological Reserve (Fig. 2K), although the animal was left in the wild (Marcos Felipe R. Pinto, pers. comm). In general, records of this species in southeastern Brazil have become increasingly rare over the past four decades, probably due to the loss and fragmentation of habitats. In addition to the species listed as threatened in the state (Rocha et al., 2000), it is important to consider species that have not been recorded in herpetological collections for some time, such as Clelia plumbea, which has been collected only rarely in recent decades in the state. This highlights the need for a detailed review of the list of endangered species of Rio de Janeiro state.

Reptile species are threatened worldwide for several reasons as, for example, habitat loss or climate change. Global warming is provoking species extinction on a major scale, and lizard populations are currently being extirpated from all the continents on which reptiles are found (Sinervo et al., 2010; Diele-Viegas et al., 2020). Rising environmental temperatures lead to a reduction in the thermal niche, by reducing the number of hours a day that a species can remain active without overheating (Sinervo et al., 2010; Diele-Viegas et al., 2019). The combined ef- 
fects of habitat loss and global warming, together with species endemism, contribute to a preoccupying scenario for these species, and may greatly increase the risk of extinction, especially for the species that are already endangered. This scenario is worrying for lepidosaurian species around the world (Diele-Viegas et al., 2020) and this reinforces the need for the development of adequate policies for the protection and conservation of reptile species, most of which are under considerable threat, and are likely to suffer extinction, on some scale, in the near future (Sinervo et al., 2010). These conservation initiatives are needed urgently in species-rich regions such as Rio de Janeiro state. One complementary strategy is the reintroduction of species, as in the case of Liolaemus lutzae, following a systematic program of habitat recovery, which allowed the species to return to its area of origin (Rocha et al., 2009c). Special care is also required for the endemic and threatened lizard Glaucomastix littorallis, which is now restricted to only four isolated areas of restinga, one of the most impacted and endangered ecosystems in Brazil.

As the most recent evaluation of the conservation status of the reptiles of Rio de Janeiro was published two decades ago (Rocha et al., 2000), the findings of the present study reinforce the need for a revision of the listing. Clearly, new inventories are also still needed, in particular in the north of the state, and the results of this research will also be important for the development of effective public conservation policies. Taxonomic studies are also needed to clarify unresolved issues in specific reptile groups, in order to best elucidate their phylogenetic relationships. A better understanding of the distribution patterns of the reptile species found in the state of Rio de Janeiro and their association with habitat loss and knowledge gaps on the ecology of the state's fauna will contribute to the management of protected areas and the creation of new conservation units in the state.

\section{Authors' Contributions Statement}

JCFO, RCG and PP identified the species in herpetological collections and wrote the manuscript. All the authors actively participated in the results, discussion, reviewed and approved the final version of the paper.

\section{ACKNOWLEDGMENTS}

This study is part of the results of the "Programa de Pesquisas em Biodiversidade da Mata Atlântica (PPBio Mata Atlântica Program)" of Ministério do Meio Ambiente do Brasil (MMA) supported by Conselho Nacional de Desenvolvimento CientíficoeTecnológico (CNPq) (process № 457458/2102-7). CFDR thanks to Conselho Nacional do Desenvolvimento Científico e Tecnológico (CNPq, grants 302974/2015-6 and 424473/2016), Biota FAPERJ Program (E-26/10.1639/2014) and through "Cientistas do Nosso Estado" program from Fundação Carlos Chagas Filho de Amparo à Pesquisa do Estado do Rio de Janeiro - FAPERJ (processes № E-26/202.920.2015 and E-26/202.803/2018). We thank Daniel S. Fernandes, Bárbara C.S. Francisco, Pedro C. Prado, Pedro M.S. Nunes, Pedro Pinna and Vivian Trevine for their valuable suggestions and contribution and Dr. Stephen Ferrari for revising English grammar. JCFO thanks to FAPERJ for postdoctoral fellowship grant (Process E-26/202.388/2017). PP had financial support from Conselho Nacional de Desenvolvimento Científico e Tecnológico (processes 306227/2015-0, 439375/2016-9, 302611/2018-5 and 309560/2018-7) and Fundação Carlos Chagas Filho de Amparo à Pesquisa do Estado do Rio de Janeiro (E-26/202.737/2018).

\section{REFERENCES}

Arteaga, A.; Salazar-Valenzuela, D.; Mebert, K.; Peñafiel, N.; Aguiar, G.; Sánchez-Nivicela, J.C.; Pyron, R.A.; Colston, T.J.; Cisneros-Heredia, D.F.; Yánez-Muñoz, M.H. \& Venegas, P.J. 2018. Systematics of South American snail-eating snakes (Serpentes, Dipsadini), with the description of five new species from Ecuador and Peru. Zookeys, 766: 79-147.

Ávila-Pires, T.C.S.; Hoogmoed, M.S. \& Rocha, W.A. 2010. Notes on the vertebrates of northern Pará, Brazil: a forgotten part of the Guianan region, I. Herpetofauna. Boletim do Museu Paraense Emílio Goeldi. Série Ciências Naturais, 5: 13-112.

Barth, R. 1957. A fauna do Parque Nacional de Itatiaia. Boletim do Parque Nacional de Itatiaia, Rio de Janeiro, 6: 1-150.

Bastos, E.G.M.; Araújo, A.F.B. \& Silva, H.R. 2005. Records of the rattlesnake Crotalus durissus (Laurenti) (Serpentes, Viperidae) in the State of Rio de Janeiro, Brazil: a possible case of invasion facilitated by deforestation. Revista Brasileira de Zoologia, 22: 812-815.

Bergallo, H.G.; Fidalgo, E.C.; Rocha, C.F.D.; Uzêda, M.C.; Costa, M.B.; Alves, M.A.S.; Van Sluys, M.; Santos, M.A.; Costa, T.C.C. \& Cozzolino, A.C.R. 2009. Estratégias e ações para a conservação da biodiversidade no Estado do Rio de Janeiro. Rio de Janeiro, Instituto Biomas.

Borges-Martins, M. 1998. Revisão taxonômica e sistemática filogenética do gênero Ophiodes Wagler, 1828 (Sauria, Anguidae, Diploglossinae). (Doctoral Thesis). Porto Alegre, Pontifícia Universidade Católica do Rio Grande do Sul.

Campbell, J.A. \& Lamar, W.W. 2004. The venomous reptiles of Latin América. Ithaca, Cornell University Press.

Citeli, N.; Hamdan, B. \& Guedes, T. 2016. Snake richness in urban forest fragments from Niterói and surroundings, state of Rio de Janeiro, southeastern Brazil. Biodiversity Data Journal, 4: e7145. D0I

Colombo, A.F. \& Joly, C.A. 2010. Brazilian Atlantic Forest lato sensu: the most ancient Brazilian forest, and a biodiversity hotspot, is highly threatened by climate change. Brazilian Journal of Biology, 70: 697-708.

Costa, H.C. \& Bérnils, R.S. 2018. Répteis do Brasil e suas unidades federativas: Lista de espécies. Herpetologia Brasileira, 7: 11-57.

Diele-Viegas, L.M.; Figueiroa, R.T.; Vilela, B. \& Rocha, C.F.D. 2020. Are reptiles toast? A worldwide evaluation of Lepidosauria vulnerability to climate change. Climatic Change, 159: 1-17.

Diele-Viegas, L.M.; Werneck, F.P. \& Rocha, C.F.D. 2019. Climate change effects on population dynamics of three species of Amazonian lizards. Comparative Biochemistry and Physiology Part A: Molecular \& Integrative Physiology, 236: 1-8.

Dorigo, T.A. 2017. Vivendo em uma floresta replantada: anfibios e répteis do maciço da Tijuca, Município do Rio de Janeiro, Sudeste do Brasil. (Tese Doutorado em Ecologia e Evolução). Rio de Janeiro, Universidade do Estado do Rio de Janeiro. 
Ernst, C.H. \& Lovich, J.E. 2009. Turtles of the United States and Canada. 2.ed. Baltimore, John Hopkins University Press. 827p.

Fernandes, D.S.; Marques, 0.A.V. \& Argôlo, A.J.S. 2010. A new species of Dipsas Laurenti from the Atlantic Forest of Brazil (Serpentes: Dipsadidae). Zootaxa, 2691: 57-66.

Fritz, U. \& Havas, P. 2006. Checklist of Chelonians of the World. Vertebrate Zoology, 57(2): 149-368.

Goyannes-Araújo, P.; Almeida-Gomes, M.; Borges-Junior, V.N.T.; Albuquerque, H.G.; Vrcibradic, D. \& Rocha, C.F.D. 2009. Reptilia, Polychrotidae, Anolis fuscoauratus: Distribution extension. Check List, 5: 746-748.

Hamdan, B.; Machado, C. \& Citeli, N.K. 2015. Filling gaps and a new state record of Xenopholis scalaris (Wucherer, 1861) (Serpentes: Dipsadidae). Check List, 11(5): 1-3.

Hoogmoed, M.S.; Fernandes, R.; Kucharzewski, C.; Moura-Leite, J.C.; Bérnils, R.S.; Entiauspe-Neto, 0.M. \& Santos, F.P.R. 2019. Synonymization of Uromacer ricardinii Peracca, 1897 with Dendrophis aurata Schlegel, 1837 (Reptilia: Squamata: Colubridae: Dipsadinae), a rare South American snake with a disjunct distribution. South American Journal of Herpetology, 14: 88-102.

Instituto Chico Mendes de Conservação da Biodiversidade (ICMBio). 2018. Livro Vermelho da Fauna Brasileira Ameaçada de Extinção. Brasilia, ICMBio/MMA.v.1.

International Union for Conservation of Nature and Natural Resources (IUCN). 2019. The IUCN Red List of Threatened Species. Version 2019-2. http:// www.iucnredlist.org. Access in: 18/08/2019.

Jackson, J.B.C.; Kirby, M.X.; Berger, W.H.; Bjorndal, K.A.; Botsford, L.W.; Bourque, B.J.; Bradbury, R.H.; Cooke, R.; Erlandson, J.; Estes, J.A.; Hughes, T.P.; Kidwell, S.; Lange, C.B.; Lenihan, H.S.; Pandolfi, J.M.; Peterson, C.H.; Steneck, R.S.; Tegner, M.J. \& Warner, R.R. 2001. Historical overfishing and the recent collapse of coastal ecosystems. Science, 293: 629-637.

Kolbe, J.J.; Glor, R.E.; Schettino, L.R.; Lara, A.C.; Larson, A.; Losos, J.B. 2004. Genetic variation increases during biological invasion by a Cuban lizard. Nature, London, 431: 177-181.

Leite, Y.L.R.; Costa, L.P.; Loss, A.C.; Rocha, R.G.; Batalha-Filho, H.; Bastos, A.C.; Quaresma, V.S.; Fagundes, V.; Paresque, R.; Passamani, M. \& Pardini, R. 2016. Neotropical forest expansion dusking the last glacial period challenges refuge hypothesis. Proceedings of the National Academy of Sciences, 113: 1008-1013.

Martins, A.; Pontes, R.; Mattedi, C.; Murta-Fonseca, R.A.; Fratani, J.; Ramos, L.O.; Brandão, A.L.R.; Maciel, D.B. \& Pinto, R.R. 2019. Herpetofauna community from coastal restinga remnants in Northeast Rio de Janeiro state, Brazil. Journal of Coastal Conservation, 23: 1019-1037. D0l

Montingelli, G.G.; Grazziotin, F.G.; Battilana, J.; Murphy, R.W.; Zhang, Y.P. \& Zaher, H. 2019. Higher-level phylogenetic affinities of the Neotropical genus Mastigodryas Amaral, 1934 (Serpentes: Colubridae), species-group definition and description of a new genus for Mastigodryas bifossatus. Journal of Zoological Systematics and Evolutionary Research, 57(2): 205-239.

Myers, N.; Mittermeier, R.A.; Mittermeier, C.G.; Fonseca, G.A.B. \& Kent, J. 2000. Biodiversity hotspots for conservation priorities. Nature, London, 403: 853-858.

Nicholson, K.E.; Crother, B.I.; Guyer, G. \& Savage, J.M. 2018. Translating a clade based classification into one that is valid under the international code of zoological nomenclature: the case of the lizards of the family Dactyloidae (Order Squamata). Zootaxa, 4461(4): 573-586.

Oliveira, J.C.F.; Castro, T.M.C.; Vrcibradic, D.; Drago, M. \& Prates, I. 2018. A second Caribbean anole lizard species introduced to Brazil. Herpetology Notes, 11: 761-764.

Oliveira, J.C.F.; Ribeiro, J.P.; Winck, G.R.; Rocha, C.F.D.; Pralon, E.; Silva, M.B. \& Avila-Pires, T.C.S. 2015. Cnemidophorus cryptus Geographic distribution. Herpetological Review, 46: 58-59.
Oliveira, J.C.F.; Winck, G.R.; Pereira-Ribeiro, J. \& Rocha, C.F.D. 2016. Antropogenic effect or niche preference? contributions to the knowledge of Hemidactylus mabouia invasion in South America. North-Western Journal of Zoology, 12: 389-392.

Passos, P.; Fernandes, R.; Bérnils, R.S. \& Moura-Leite, J.C. 2010. Taxonomic revision of the Brazilian Atlantic Forest Atractus (Reptilia: Serpentes: Dipsadidae). Zootaxa, 2364: 1-63.

Peters, J.A. \& Donoso-Barros, R. 1970. Catalogue of the Neotropical Squamata. Part II. Lizards and Amphisbaenians. Bulletin of the United States National Museum, 297: 1-293.

Pinto, L.P.; Bedê, L.; Paese, A.; Fonseca, M.; Paglia, A. \& Lamas, I. 2006. Mata Atlântica Brasileira: Os desafios para a conservação da biodiversidade de um hotspot mundial. In: Rocha, C.F.D.; Bergallo, H.G.; Van Sluys, M. \& Alves, M.A.S. (Eds.). Biologia da conservação: essências. São Carlos, Rima Editora. p. 91-118.

Poe, S.; Nieto-Montes de 0ca, A.; Torres-Carvajal, 0.; de Queiroz, K.; Velasco, J.A.; Truett, B.; Gray, L.N.; Ryan, M.J.; Köhler, G.; Ayala-Varela, F. \& Latella, I. 2017. A phylogenetic, biogeographic, and taxonomic study of all extant species of Anolis (Squamata; Iguanidae). Systematic Biology, 66(5): 663-697.

Powell, R.; Conant, R. \& Collins, J.T. 2016. Peterson field guide to Reptiles and Amphibians of Eastern and Central North America. 4.ed. Boston, Houghton Mifflin Harcourt. 608p.

Prates, I.; Melo-Sampaio, P.R.; de Queiroz, K.; Carnaval, A.C.; Rodrigues, M.T. \& Drummond, L.0. 2020. Discovery of a new species of Anolis lizard from Brazil and its implications for the historical biogeography of montane Atlantic Forest endemics. Amphibia-Reptilia, 41: 87-103.

Ranta, P.; Blom, T.; Niemelä, J.; Joensuu, E. \& Siitonen, M. 1998. The fragmented Atlantic rain forest of Brazil: size, shape and distribution of forest fragments. Biodiversity and Conservation, 7: 385-403.

Ribeiro, M.C.; Metzger, J.P.; Martensen, A.C.; Ponzoni, F.J. \& Hirota, M.M. 2009. The Brazilian Atlantic Forest: how much is left, and how is the remaining forest distributed? Implications for conservation. Biological Conservation, 142(6): 1141-1153.

Rocha, C.F.D. \& Bergallo, H.G. 2011. Conquering Brazil: the invasion by the exotic gekkonid lizard Hemidactylus mabouia (Squamata) in Brazilian natural environments. Zoologia, Curitiba, 28(6): 747-754.

Rocha, C.F.D.; Bergallo, H.G.; Alves, M.A.S.\&Van Sluys, M. 2003. A biodiversidade nos grandes remanescentes florestais do Estado do Rio de Janeiro e nas restingas dos corredores da Mata Atlântica. São Carlos, Rima Editora. 156p.

Rocha, C.F.D.; Bergallo, H.G.; Pombal Jr., J.P.; Geise, L.E.; Van Sluys, M. Fernandes, R.0. \& Caramaschi, U. 2004. Fauna de anfíbios, répteis e mamíferos do Estado do Rio de Janeiro, sudeste do Brasil. Publicações Avulsas do Museu Nacional, 104: 3-23.

Rocha, C.F.D.; Bergallo, H.G.; Van Sluys, M. \& Alves, M.A.S. 2000. As listas de fauna ameaçada: as discrepâncias regionais e a importância e 0 significado de listas. In: Bergallo, H.G.; Rocha, C.F.D.; Alves, M.A.S. \& Van Sluys, M. A Fauna Ameaçada de extinção do Estado do Rio de Janeiro. Rio de Janeiro, Editora da Universidade do Estado do Rio de Janeiro EDUERJ. p. 11-16.

Rocha, C.F.D.; Bergallo, H.G.; Van Sluys, M. \& Alves, M.A.S. 2006. Corredores Ecológicos e Conservação da Biodiversidade: um estudo de caso na Mata Atlântica. In: Bergallo, H.G.; Rocha, C.F.D.; Alves, M.A.S. \& Van Sluys, M. Biologia da conservação: essências. São Carlos, Editora Rima. p. 317-342.

Rocha, C.F.D.; Bergallo, H.G.; Van Sluys, M.; Alves, M.A.S. \& Jamel, C.E. 2007. The remnants of restinga habitats in the Brazilian Atlantic Forest of Rio de Janeiro state, Brazil: Habitat loss and risk of disappearance. Brazilian Journal of Biology, 67(2): 263-273.

Rocha, C.F.D.; Kiefer, M.C.; Barros-Filho, J.D.; Araújo, A.F.B.; Siqueira, C.C. \& Van Sluys, M. 2009a. Répteis e sua conservação no Estado do Rio de Janeiro. 
In: Bergallo, H.G.; Rocha, C.F.D.; Alves, M.A.S. \& Van Sluys, M. A Fauna Ameaçada de extinção do Estado do Rio de Janeiro. Rio de Janeiro, Editora da Universidade do Estado do Rio de Janeiro - EDUERJ. p. 11-16.

Rocha, C.F.D.; Siqueira, C.C. \& Ariani, C.V. 2009b. The endemic and threatened lizard Liolaemus lutzae (Squamata: Liolaemidae): current geographic distribution and areas of occurrence with estimated population densities. Zoologia, Curitiba, 26(3): 454-460.

Rocha, C.F.D.; Siqueira, C.C. \& Ariani, C.V. 2009c. A potential recovery of a population of the sand lizard Liolaemus lutzae Mertens, 1938 in an area within its range: a lizard endemic and threatened with extinction. Brazilian Journal of Biology, 69(1): 185-187.

Rocha, C.F.D.; Telles, F.B.S.; Vrcibradic, D. \& Nogueira-Costa, P. 2018. The herpetofauna from Ilha Grande (Angra dos Reis, Rio de Janeiro, Brazil): updating species composition, richness, distribution and endemisms. Papéis Avulsos de Zoologia, 58(25): 1-12, e20185825.

Rodrigues, M.T. 2005. The conservation of Brazilian reptiles: challenges for a megadiverse country. Conservation Biology, 19(3): 659-664.

Salles, R.0.L. \& Silva-Soares, T. 2010. Répteis do município de Duque de Caxias, Baixada Fluminense, Rio de Janeiro, Sudeste do Brasil. Biotemas, 23: 135-144.

Siciliano, S.; Moura, J.F.; Tavares, D.C.; Amorim, C.R.S. \& Matias C.A.R. 2014. On the intriguing occurrence of Rhinoclemmys punctularia (Daudin, 1801) in coastal plains of eastern Rio de Janeiro, Brazil. Herpetology Notes, 7: 667-671.

Silveira, A.L. 2008. Geographic distribution: Oxyrhopus guibei. Herpetological Review, 39(2): 242.

Sinervo, B.; Mendez-de-la-Cruz, F.; Miles, D.B.; Heulin, B.; Bastiaans, E.; Villagran-Santa Cruz, M.; Lara-Resendiz, R.; Martinez-Mendez, N.; Calderon-Espinosa, M.L.; Meza-Lazaro, R.N.; Gadsden, H.; Avila, L.J.; Morando, M.; De la Riva, I.J.; Sepulveda, P.V.; Rocha, C.F.D.; Ibarguengoytia, N.; Puntriano, C.A.; Massot, M.; Lepetz, V.; Oksanen, T.A.;
Chapple, D.G.; Bauer, A.M.; Branch, W.R.; Clobert, J. \& Sites Jr., J.W. 2010. Erosion of lizard diversity by climate change and altered thermal niches. Science, Washington, 328(5980): 894-899.

SOS Mata Atlântica/ Instituto Nacional de Pesquisas Espaciais (INPE). 1992/1993. Atlas evolução dos remanescentes florestais do domínio de Mata Atlântica e ecossistemas associados no período de 1985-1990. São Paulo.

SOS Mata Atlântica/Instituto Nacional de Pesquisas Espaciais (INPE). 2017/2018. Atlas dos Remanescentes Florestais da Mata Atlântica. Relatório Técnico. São Paulo.

Spix, J.V.B. 1825. Animalia nova sive species novae lacertarum quas in itinere per brasiliam annis. MDCCCXVII-MDCCCXX jussu et auspiciis Maximiliani Josephi I. Bavierae Regis suscepto collegit et descripsit Dr. J.B. de Spix. Munich, F.S. Hubshmann.

Sturaro, M.J.; Rodrigues, M.T.; Colli, G.R.; Knowles, L.L. \& Avila-Pires, T.C.S. 2018. Integrative taxonomy of the lizards (ercosaura ocellata species complex (Reptilia: Gymnophthalmidae). Zoologischer Anzeiger, 275(1): 37-65.

Tozetti, A.M.; Sawaya, R.J.; Molina, F.B.; Bérnils, R.S.; Barbo, F.E.; Leite, J.C.M.; Borges-Martins, M.; Recoder, R.; Teixeira Junior, M.; Argôlo, A.J.S.; Morato, S.A.A. \& Rodrigues, M.T. 2018. Répteis. In: Monteiro-Filho, E.L.A. \& Conte, C.E. (Orgs.). Revisões em zoologia: Mata Atlântica. Curitiba, Ed. UFPR.

Vrcibradic, D.; Van Sluys, M.; Ariani, C.; Rocha, C.F.D.; Kiefer, M.C.; Rubião, E.; Hatano, F.H.; Fontes, A.; Borges-Junior, V.N.; Almeida-Gomes, M. \& Klaion, T. 2011. Herpetofauna, Estação Ecológica Estadual do Paraíso, state of Rio de Janeiro, southeastern Brazil. Check List, 7: 745-749.

Wariss, M.; Isaac, V.J. \& Pezzuti, J.C.B. 2012. Habitat use, size structure and sex ratio of the spot-legged turtle, Rhinoclemmys punctularia punctularia (Testudines: Geoemydidae), in Algodoal-Maiandeua Island, Pará, Brazil. Revista de Biología Tropical, 60: 413-424. 